\title{
A multi-decadal history of biomass burning plume heights identified using aerosol index measurements
}

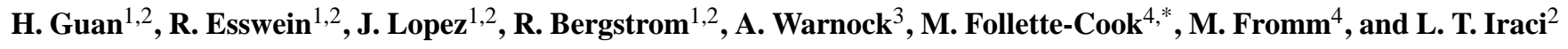 \\ ${ }^{1}$ Bay Area Environmental Research Institute, Sonoma, CA, USA \\ ${ }^{2}$ NASA Ames Research Center, Moffett Field, CA, USA \\ ${ }^{3}$ University of Michigan, Ann Arbor, MI, USA \\ ${ }^{4}$ Remote Sensing Division, Naval Research Laboratory, Washington DC, USA \\ * currently at: Goddard Earth Sciences and Technology Center, University of Maryland Baltimore County, \\ Baltimore, MD, USA
}

Received: 14 November 2009 - Published in Atmos. Chem. Phys. Discuss.: 5 January 2010

Revised: 2 July 2010 - Accepted: 5 July 2010 - Published: 16 July 2010

\begin{abstract}
We have quantified the relationship between Aerosol Index (AI) measurements and plume height for young biomass burning plumes using coincident Ozone Monitoring Instrument (OMI) and Cloud-Aerosol Lidar and Infrared Pathfinder Satellite Observations (CALIPSO) measurements. This linear relationship allows the determination of high-altitude plumes wherever AI data are available, and it provides a data set for validating global fire plume heights in chemistry transport models. We find that all plumes detected from June 2006 to February 2009 with an AI value $\geq 9$ are located at altitudes higher than $5 \mathrm{~km}$. Older high-altitude plumes have lower AI values than young plumes at similar altitudes. We have examined available AI data from the OMI and TOMS instruments (1978-2009) and find that large AI plumes occur more frequently over North America than over Australia or Russia/Northeast Asia. According to the derived relationship, during this time interval, 181 plumes, in various stages of their evolution, reached altitudes above $8 \mathrm{~km}$.
\end{abstract}

\section{Introduction}

Knowledge of the injection and transport altitudes of biomass burning plumes is crucial for understanding the long range transport of particles and reactive gases that can substantially alter the radiation balance and chemistry of the atmosphere (Cofer et al., 1996; Waibel et al., 1999; Forster et al., 2001; Jost et al., 2004; Luderer et al., 2006; Randerson et al., 2006; Trentmann et al., 2006; IPCC, 2007; Jeong

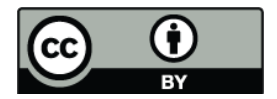

Correspondence to: H. Guan (hong.guan-1@nasa.gov) and Hsu, 2008). Remote and in-situ observations have documented many instances of biomass burning pollutants in the upper troposphere and lower stratosphere (UT/LS) (Fromm and Servranckx, 2003; Jost et al., 2004; Rosenfeld et al., 2007).

To date, biomass burning plume heights have typically been determined in a case-by-case manner. For instance, using Polar Ozone and Aerosol Measurement III (POAM III) observations and back trajectories (Fromm and Servranckx, 2003; Rosenfeld et al., 2007; Fromm et al., 2008a, b), the May 2001 Chisholm fire in Alberta, Canada was determined to have penetrated the tropopause. In the northern summer of 2001 over 200 observations of aerosol layers were measured by the POAM III mission, half of which were in the stratosphere (Fromm and Servranckx, 2003). Another case study involved detection of high $\mathrm{CO}$ values $2 \mathrm{~km}$ above the tropopause south of Florida during an aircraft campaign in July 2002 (Jost et al., 2004). Particle measurements by the Particle Analysis by Laser Mass Spectrometry (PALMS) instrument helped corroborate the biomass-burning signature. In addition, isentropic back trajectories placed the air mass under a POAM III enhanced aerosol feature over Canada, showing evidence of stratospheric transport far from the observation location.

Mazzoni et al. (2007) used Multi-angle Imaging SpectroRadiometer (MISR) and Moderate Resolution Imaging Spectroradiometer (MODIS) data to locate fires and their associated smoke plumes and retrieved the injection heights generated by fire buoyancy over a four-month period. Smoke plume injection height is defined as the altitude at which the smoke particles are injected to the atmosphere before transport (Kahn et al., 2008). Mazzoni et al. found a total of 325 candidate plumes, of which 138 were identified as

Published by Copernicus Publications on behalf of the European Geosciences Union. 
biomass burning plumes, none of which were classified as stratospheric. Kahn et al. (2008) further assessed smoke injection height for a similar region and period. They noted that at least about $10 \%$ of wildfire smoke plumes reached the free troposphere but remained lower than $5 \mathrm{~km}$. This low-altitude bias may be inherent in their selection criteria, as their plume observations are limited to the overpass time (11:00-14:00 local time in North America, Val Martin et al., 2010) of the Terra satellite, when fires have not yet reached their maximum intensity.

Val Martin et al. (2010) extended the work of Mazzoni et al. (2007) by analyzing a 5-year record of MISR smoke plume injection heights over North America and correlating them with MODIS fire radiative power measurements. That study highlighted a physical relationship which could be explored to estimate injection heights for low-altitude fire plumes (lower than $7 \mathrm{~km}$ ).

Recently, Jeong and Hsu (2008) presented a new algorithm that predicts the height of smoke aerosols associated with biomass burning when Aerosol Index (AI), single scattering albedo (SSA), and optical depth are known. They showed that for a specific biomass burning plume over the northwest United States (15 August 2007), the predicted height and the Cloud-Aerosol Lidar and Infrared Pathfinder Satellite Observations (CALIPSO) measured height are in relatively good agreement (correlation coefficient $=0.86$ ). Their results showed that satellite data can be exploited in studies of larger scope.

Several models have been used to assess the impact of biomass burning pollution on the stratosphere (e.g. Luderer et al., 2006; Trentmann et al., 2006), the UT/LS (e.g. Duncan, 2007) and the troposphere (e.g. Kuester et al., 2005; Li et al., 2005). The injection height of smoke plumes from forest fires is a key input for aerosol transport modeling, as the height is critical for determining the distance and direction the smoke will travel (Westphal and Toon, 1991; Ginoux et al., 2001; Colarco et al., 2004). However, the injection height is a large source of uncertainty in these models. Recently, efforts have been made to apply more realistic injection heights in chemistry transport models. These physically-based (Freitas et al., 2007; Guan et al., 2008) or MISR-derived (Chen et al., 2009) injection heights have only been validated in certain regions and for limited periods. In order to minimize uncertainties and limitations, it is important to use a database of seasonally and regionally diverse plume heights, rather than simply compare model results to a handful of case studies.

We have developed a simple empirical method using the AI as determined by the Ozone Monitoring Instrument (OMI) and Total Ozone Mapping Spectrometer (TOMS) instruments to identify biomass burning plume heights. The $\mathrm{AI}$ is a useful tool for detecting UV-absorbing aerosols since it is derived from the measurement of the reflectance at two wavelengths in the UV coupled with radiative transfer modeling of the Rayleigh atmosphere. The AI is particularly sensitive to high-altitude aerosols and has a multi-decadal histor- ical data set. We have used plume altitudes measured from the CALIOP instrument to develop a method for screening the entire AI data record for high altitude plumes. Using the relationship developed when altitude measurements are available, we screened the entire AI record and assembled a climatology of high-altitude biomass burning plumes from 1978 to 2009. In addition to providing a long-term, global data set for model validation, our data set also reveals the patterns and numbers of high altitude biomass burning plumes in several regions worldwide.

\section{Satellite data sets}

\subsection{Aerosol Index data}

The AI is a measure of how backscattered ultraviolet (UV) radiation from an atmosphere containing aerosols differs from that of a pure molecular atmosphere. ${ }^{1} \mathrm{AI}$ is especially sensitive to the presence of UV absorbing aerosols such as smoke, mineral dust, and volcanic ash. The index value is positive when absorbing aerosols are present, whereas clouds yield a nearly zero value of AI. Torres et al. (1998) and Jeong and Hsu (2008) showed that AI varies with aerosol layer height, optical depth and single scattering albedo. High and optically-thick absorbing aerosol layers more effectively reduce the scattered light from the Rayleigh scattering below the aerosol layer. In cloud-free conditions, the highest and thickest absorbing aerosols give the largest AI values. Absorbing aerosols can still be detected if mixed with clouds or located above clouds.

The TOMS instruments onboard the Nimbus 7 (19781993) and Earth Probe (1996-2005) satellites and the OMI onboard the EOS-Aura (2004-present) satellite provide a nearly continuous and long term record of AI suitable for scientific applications. The TOMS and OMI AI datasets are derived using the same methodology and wavelength channel (Ahmad et al., 2006; Li et al., 2009). The consistency of both datasets has been demonstrated in a recent study ( $\mathrm{Li}$ et al., 2009), offering a basis for

\footnotetext{
${ }^{1} \mathrm{AI}$ is defined as:

$\mathrm{AI}(\tau, \omega, z)=100\left(\log _{10}\left(I_{360}\right.\right.$ meas $\left.\left./ I_{331 \text { meas }}\right)-\log _{10}\left(I_{360 \text { calc }}\left(R_{\mathrm{sfc}}\right) / I_{331 \text { calc }}\left(R_{\mathrm{sfc}}\right)\right)\right)$,

where $I$ is the radiance (or intensity) measured by the satellite or calculated for a purely molecular scattering atmosphere and $R_{\mathrm{sfc}}$ is the Lambert equivalent effective reflectivity value. The variables $\tau, \omega$, and $z$ represent optical depth, single scattering albedo, and height, respectively. This rather awkward definition is due to the origin of AI as a residual from satellite measurements (the term was called an "N-valued residual" in the original Herman et al. (1997) paper). In practice the equation reduces to the negative of 100 times the log base 10 of the ratio of the measured radiance at a wavelength divided by the radiance that would be observed if the atmosphere had only molecular scattering. The use of AI has been discussed in a number of papers (Torres et al., 1998; Jeong and Hsu, 2008).
} 


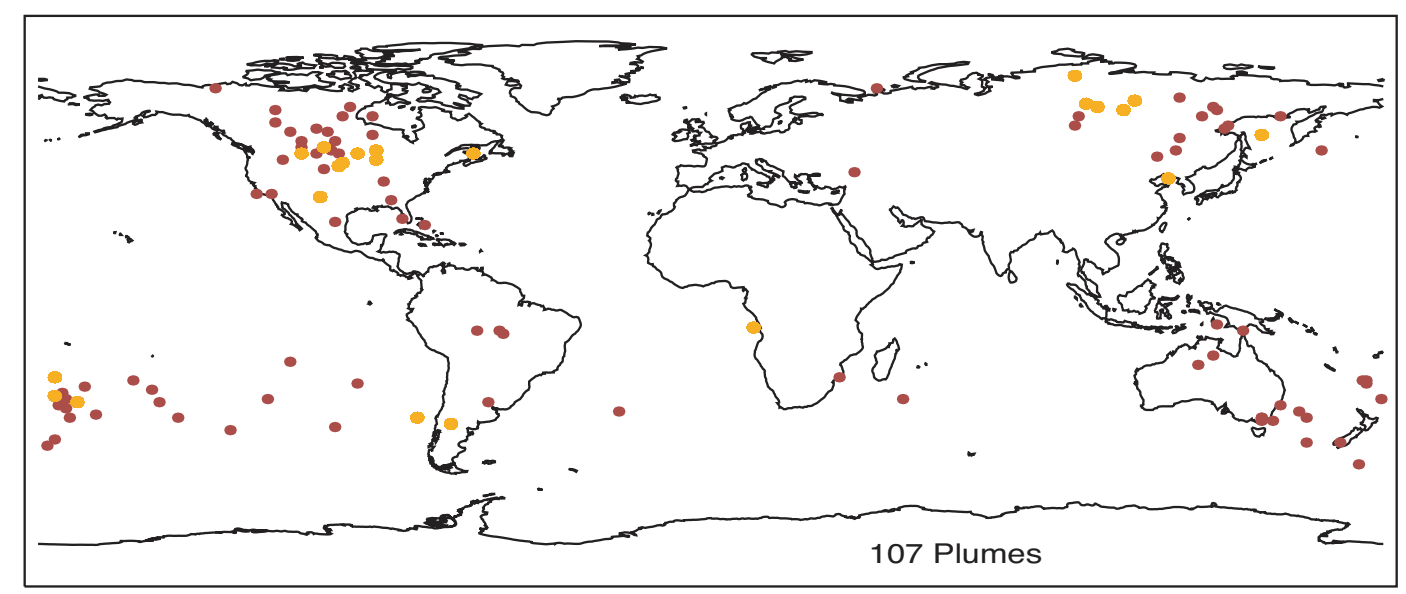

Fig. 1. Locations of AI plumes encountered during the CALIPSO era (1 June 2006 to 13 February 2009). An aerosol plume is defined as containing at least 1 pixel with $\mathrm{AI} \geq 7$ and at least 3 adjacent pixels with $\mathrm{AI} \geq 4$. Orange and red symbols represent the cases with and without coincident AI and CALIPSO measurements, respectively.

combined studies (Gautam et al., 2009). Daily TOMS version 8 Level $3\left(1.25^{\circ} \times 1^{\circ}\right.$ resolution) and OMI Collection 3 $\left(1^{\circ} \times 1^{\circ}\right.$ resolution) were obtained from the NASA/GSFC TOMS website (http://toms.gsfc.nasa.gov/aerosols/aerosols. html, updated June 2009). TOMS AI data was unavailable between May 1993 and September 1996. Additionally, the EP-TOMS AI data after July 2000 were not included in this study due to the calibration drift of the sensor (Kiss et al., 2007).

Over bright clouds, AI values are enhanced due to the effect of the radiative transfer interactions between the bright underlying cloud and the absorbing layer (Hsu et al., 2004; Torres et al., 2007) and do not represent actual differences in aerosol physical properties. To avoid the enhanced effect of underlying clouds on AI, we screened out cloudy pixels that contained a cloud fraction (for OMI) or a reflectivity (for TOMS) of greater than 0.2 (personal communication, O. Torres, 2008).

\subsection{CALIPSO data}

CALIPSO's lidar instrument, the Cloud-Aerosol Lidar with Orthogonal Polarization (CALIOP), provides high resolution vertical profiles of aerosol and cloud attenuated backscatter signals at $532 \mathrm{~nm}$ and $1064 \mathrm{~nm}$ (Winker et al., 2007). The footprint of the lidar beam has a $100 \mathrm{~m}$ cross-section (Thomason et al., 2007) with an overpass around 1:30 p.m. local time. CALIPSO gives limited coverage relative to OMI $($ swath $=2600 \mathrm{~km})($ Eckhardt et al., 2008).

Several products derived from the backscatter signals were used in this study. They included the version 2 Vertical Feature Mask (VFM) (Vaughan et al., 2004), the $532 \mathrm{~nm}$ total attenuated backscatter, the depolarization ratio (the ratio of the perpendicular component of the backscatter to the parallel component), and the color ratio (the ratio of backscatter at $1064 \mathrm{~nm}$ to $532 \mathrm{~nm}$ ). We used the VFM product to determine the top heights of features and then further distinguished the aerosol from cloud by checking the $532 \mathrm{~nm}$ total attenuated backscatter, depolarization ratio, and color ratio. Details on distinguishing aerosols from clouds are described in Sect. 3.

\subsection{MODIS fire data}

Additionally, MODIS fire count maps were used to detect the location and time of fires for the 2004-2009 period. Fire count data are available online at http://firefly.geog.umd.edu/ firemap/.

\section{Identification methodology for high-altitude plumes}

We first used the AI data product to locate large aerosol plumes, defined as containing at least 1 pixel with $\mathrm{AI} \geq 7$ and at least 2 (TOMS) or 3 (OMI) adjacent pixels with $\mathrm{AI} \geq 4$. We found 1479 plumes over the AI record period (19782009, see Sect. 2.1 for specific dates). From that set, large AI observations caused by solar eclipses and volcanoes were removed. Major desert regions which are likely influenced by dust rather than smoke, such as North Africa and the Middle East, were excluded. Because the dust storm season overlaps with the wildfire season in Russia, Mongolia, and Northeast China, we screened out potential dust cases over the downwind regions of the Gobi and Taklamakan Deserts during spring by checking the MODIS fire product for the time period that a plume was first observable or by tracking the plume's geographical origin. In addition, news reports and published literature were used as tools in linking an aerosol plume to a dust signal, which was then removed from further analysis. We found 107 AI plumes likely due to smoke aerosol during the CALIPSO era (1 June 2006 to 13 February 2009). The location of these smoke plumes is displayed in Fig. 1. 


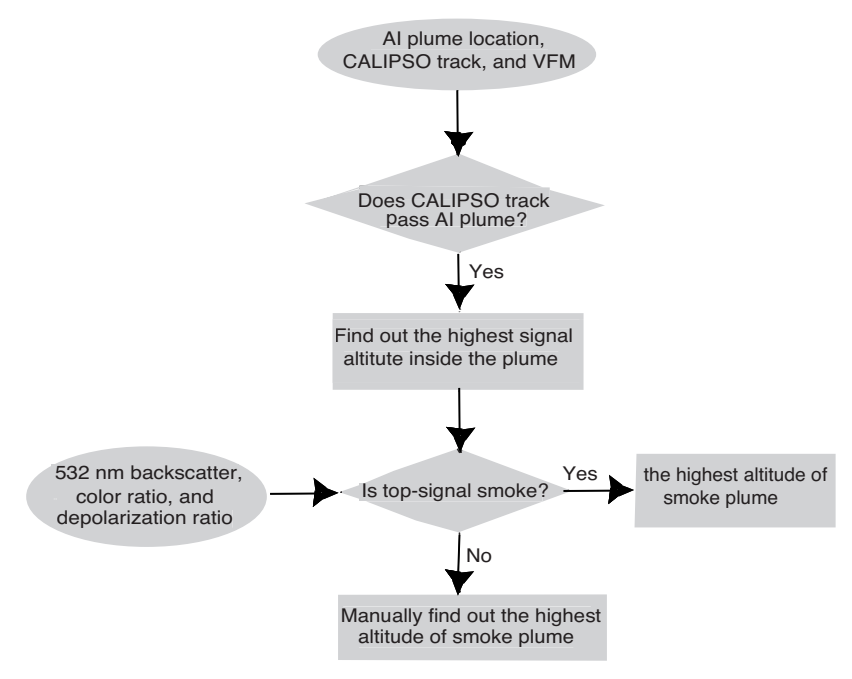

Fig. 2. Flowchart for the determination of highest plume altitude along the CALIPSO track.

Once the smoke plumes were located, we determined the plume altitude following the steps highlighted in the flowchart of Fig. 2. We first used the CALIPSO level 2 VFM data to find the plume altitude. If the CALIPSO day track passed through the AI plume, we found the highest CALIPSO signal height inside the AI plume area. An inspection of CALIPSO images for all plume cases shows that plume-top heights are relatively uniform within each plume with a maximum variation within $2 \mathrm{~km}$. It should be mentioned that for an optically dense smoke layer discussed here, the median height is difficult to determine, because the lowest altitude from which the lidar signal is returned may lie well above the true base of a dense plume. Thus, our analysis addresses only plume-top heights. In cases where more than one CALIPSO track intersected the plume, the track that was closest to the location of the largest AI value was used. The highest-altitude signal observed by CALIPSO at the location of a large AI observation should be related only to absorbing aerosol, because cloud produces a near-zero AI value.

Because the AI grid may contain sub-pixel sized clouds, which can be explicitly detected by the high-resolution CALIPSO measurement, we also checked the available 532nm total attenuated backscatter, CALIPSO depolarization ratio, and the color ratio images for each case to validate that the high-altitude signals did represent smoke aerosols. Unlike clouds, thin smoke plumes have a weak $532 \mathrm{~nm}$ total attenuated backscatter signal; dense plumes may have a $532 \mathrm{~nm}$ backscatter signal similar to clouds. We distinguished dense smoke from cloud by checking for an obvious increase of color ratio with layer penetration depth coupled with low depolarization ratio (dominated by a value less than $\sim 0.1$ ) (personal communication, A. Omar, 2008). If the top signal was a cloud, we assigned the highest smokeplume height within the plume track as the top height. The

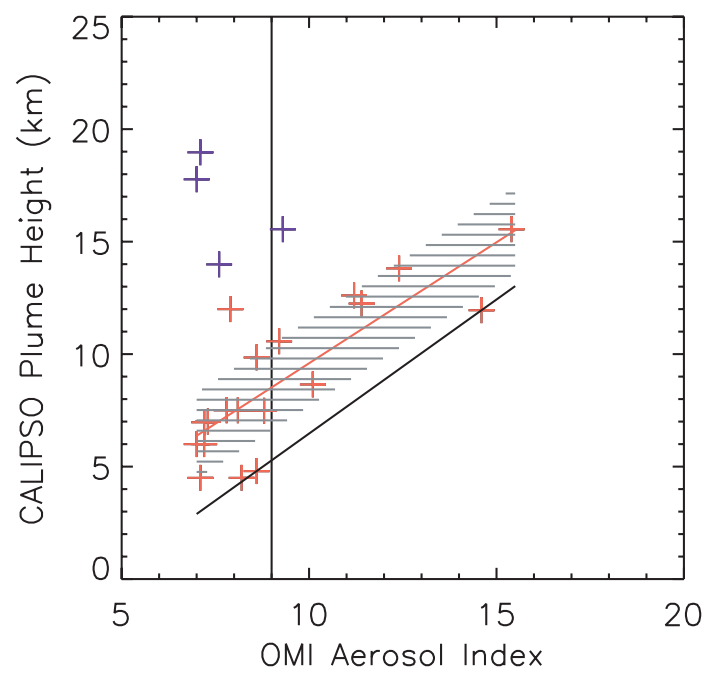

Fig. 3. Scatter-plot of OMI AI and CALIPSO maximum plume height. Red and blue symbols represent "young" and "aged" plumes, respectively. The inclined black line $(\mathrm{Z}=1.2 \mathrm{AI}-5.4)$ is the lower bound to the young plume data. The black vertical line indicates an $\mathrm{AI}$ threshold $(\mathrm{AI}=9)$ for high-altitude $(\geq 5 \mathrm{~km})$ plumes. The red line $(\mathrm{Z}=1.1 \mathrm{AI}-1.2)$ is the best fit to the young plumes. The shaded area shows a \pm 1 standard deviation $(1$-sigma $\approx 1.9 \mathrm{~km}$ ) across the best fit of the young plumes.

height uncertainty resulting from this manual assignment was approximately $\pm 0.5 \mathrm{~km}$. Using the above method, we found 23 cases of coincident AI and CALIPSO measurements which are plotted in Fig. 3 and also denoted by orange symbols in Fig. 1.

By running a back trajectory model starting at each grid point $\left(1.25^{\circ} \times 1^{\circ}\right)$ within the $23 \mathrm{AI}$ plumes and their associated maximum CALIPSO plume height, we linked each AI plume to the corresponding fire source region observed by MODIS and estimated the plume age. The trajectory model employed here was the Goddard kinematic trajectory model (Schoeberl and Newman, 1995) using National Centers for Environmental Prediction (NCEP) winds updated every $6 \mathrm{~h}$ on a $2.5^{\circ} \times 2.5^{\circ}$ grid. The maximum AI measurement time (local 1:30 p.m.) was used as the starting time of trajectory model. Plumes that can be tracked back to a fire region within 2 days were classified as "young", while plumes that have been removed from their fire regions for longer than two days were defined as "aged". We found 19 young and 4 aged plumes, which are shown in Fig. 3 as red and blue symbols, respectively. Table 1 lists the date, maximum AI and top height of each plume, its latitude and longitude of maximum AI, and age class. Additional back trajectory runs, using starting altitudes of 0.5 - and $1-\mathrm{km}$ lower than the maximum CALIPSO plume heights, have shown that the age class assigned to each plume is robust. 
Table 1. The dates of large-AI biomass burning plumes with coincident CALIPSO data.

\begin{tabular}{crrrrc}
\hline Date & $\begin{array}{r}\text { Plume height } \\
(\mathrm{km})\end{array}$ & $\begin{array}{r}\text { Maximum } \\
\text { AI }\end{array}$ & Lat. & Lon. & $\begin{array}{c}\text { Age } \\
\text { class }^{\mathrm{a}}\end{array}$ \\
\hline $7 / 24 / 06$ & 4.5 & 8.2 & 62.5 & 103.5 & $\mathrm{Y}$ \\
$7 / 25 / 06$ & 10.6 & 9.2 & 63.5 & 100.5 & $\mathrm{Y}$ \\
$7 / 26 / 06$ & 12.0 & 14.6 & 61.5 & 110.5 & $\mathrm{Y}$ \\
$7 / 27 / 06$ & 12.6 & 11.1 & 64.5 & 114.5 & $\mathrm{Y}$ \\
$7 / 27 / 06$ & 7.5 & 7.8 & 72.5 & 97.5 & $\mathrm{Y}$ \\
$9 / 05 / 06$ & 12.3 & 11.4 & 48.5 & -89.5 & $\mathrm{Y}$ \\
$9 / 05 / 06$ & 9.9 & 8.6 & 47.5 & -109.5 & $\mathrm{Y}$ \\
$12 / 19 / 06$ & 15.6 & 9.3 & -37.5 & -78.5 & $\mathrm{~A}$ \\
$12 / 19 / 06$ & 14.0 & 7.6 & -39.5 & -69.5 & $\mathrm{~A}$ \\
$5 / 26 / 07$ & 7.5 & 8.1 & 47.5 & -63.5 & $\mathrm{Y}$ \\
$6 / 10 / 07$ & 15.6 & 15.4 & 39.5 & 122.5 & $\mathrm{Y}$ \\
$7 / 08 / 07$ & 12.0 & 7.9 & 33.5 & -104.5 & $\mathrm{Y}$ \\
$7 / 30 / 07$ & 8.7 & 10.1 & 49.5 & -103.5 & $\mathrm{Y}$ \\
$8 / 01 / 07$ & 6.0 & 7.2 & 47.5 & -94.5 & $\mathrm{Y}$ \\
$8 / 01 / 07$ & 4.5 & 7.1 & -8.5 & 11.5 & $\mathrm{Y}$ \\
$8 / 13 / 07$ & 4.8 & 8.6 & 47.5 & -109.5 & $\mathrm{Y}$ \\
$8 / 14 / 07$ & 7.5 & 8.8 & 45.5 & -89.5 & $\mathrm{Y}$ \\
$8 / 15 / 07$ & 6.0 & 7.0 & 44.5 & -98.5 & $\mathrm{Y}$ \\
$8 / 17 / 07$ & 7.0 & 7.2 & 43.5 & -99.5 & $\mathrm{Y}$ \\
$7 / 02 / 08$ & 7.0 & 7.3 & 53.5 & 147.5 & $\mathrm{Y}$ \\
$2 / 09 / 09$ & 13.8 & 12.4 & -24.5 & -175.5 & $\mathrm{Y}$ \\
$2 / 11 / 09$ & 17.8 & 7.0 & -32.5 & -169.5 & $\mathrm{~A}$ \\
$2 / 12 / 09$ & 19.0 & 7.1 & -30.5 & -175.5 & $\mathrm{~A}$ \\
\hline
\end{tabular}

${ }^{\mathrm{a}} \mathrm{Y}=$ Young $(\leq 2 \mathrm{~d}$ old $)$ and $\mathrm{A}=$ Aged $(>2 \mathrm{~d}$ old $)$

\section{Results}

The inclined black line in Fig. 3 represents a minimum altitude of the top of a plume observed with a given AI value (lower bounding line):

Minimum height $(\mathrm{km})=1.2 \mathrm{AI}-5.4$

This bounding line suggests that for all plumes, when the observed AI value is larger than 9, the plume altitude is higher than $5 \mathrm{~km}$. This provides an AI threshold for identifying high-altitude injection plumes even if a direct height measurement is not available. This threshold value of AI is similar to that reported by Fromm et al. (2008b), who reported that unusually large AI values (10 or larger) were associated with smoke in the UT/LS.

While a threshold AI value is useful for categorizing high altitude plumes, there is more information that can be extracted from Fig. 3. The red line is the best-fit line to the young plumes with a corresponding equation of:

Average height $(\mathrm{km})=1.1 \mathrm{AI}-1.2$

There is a clear tendency for young plumes to show AI values increasing with increasing altitude. The correlation coefficient between AI and the altitude is 0.81 . This suggests that a common controlling process is operative in all young biomass burning plumes identified here. Using a radiative transfer model, Wong and Li (2002) showed that the topof-atmosphere reflectance at the channel-1 wavelength (centered around $0.65 \mu \mathrm{m}$ ) of the Advanced Very High Resolution Radiometer (AVHRR) sensor reached a constant value when aerosol optical depth exceeded a threshold value. The value of aerosol optical thickness at which the asymptote occurs seems to be independent of the value of SSA. More recent calculations with the wavelengths of 335.5 and $376.5 \mathrm{~nm}$ (see Penning de Vries, 2010) have reached a very similar conclusion. We hypothesize that most of the analyzed large-AI young plumes are sufficiently optically thick so that AI is close to or reaches an asymptote with respect to aerosol optical depth at $\sim 360 \mathrm{~nm}$, similar to the behavior suggested by Wong and Li's calculation for a longer wavelength (2002). When this occurs, and because the SSA is not likely to vary a great deal (Jeong and Hsu, 2008), the plume height will determine the value of AI. That is, an increasing plume height will be associated with a monotonically increasing AI, as shown in Fig. 3. Figure 3 also shows the variability of youngplume heights for a given AI value $(1$-sigma $\approx 1.9 \mathrm{~km})$. This variability may reflect physical differences between plumes as well as the uncertainty resulting from CALIPSO measuring only a small portion of a given plume. Uncertainty in the AI measurements themselves to variability in the best-fit relationship is problematic to assess (De Graaf et al., 2005a, b).

The four aged plumes (four or five days old) shown in blue in Fig. 3 indicate that at similar altitudes, aged plumes have lower AI values than young plumes. These four plumes all originated from Australian wildfires (see Table 1). Mixing with clean air as the plumes aged, was likely the driving factor in reducing the optical depth, and thus, the AI. Previous studies (Reid et al., 1998; Abel et al., 2003) also reveal that particle aging rapidly increases the SSA within several hours after the smoke is released into the atmosphere. Swap et al. (2003) indicate that chemical and physical evolution of smoke plumes is very rapid in the first hour, where after properties remain relatively stable for hours to days. These studies suggest that particle-aging processes may have a minor role in reducing the AI value for plumes older than several hours. Two of the aged plumes (with heights of 14 and $15.6 \mathrm{~km}$ ) were from a fire on 14 December 2006 (Dirksen et al., 2009), while the other two plumes (17.8 and $19 \mathrm{~km})$ were from a fire on 7 February 2009. These aged plumes were visible in the AI data for several days. Therefore we were able to record their AI values on their first observation day and estimate the corresponding heights using the trajectory model. The model was run forward starting from 15 December 2006 and 8 February 2009 at day-1 plume locations. The trajectories starting at 13.5 and $16.5 \mathrm{~km}$ pass through the CALIPSO-observed aged-plume locations and top heights, indicating the plume tops are most likely located at $13.5 \mathrm{~km}$ for the 2006 case and $16.5 \mathrm{~km}$ for the 2009 case when they were young ( 1 day old). The inferred young-plume data (red triangles) were added into the AI-plume-height plot as shown in Fig. 4. The four aged plumes (blue) were inside or near 


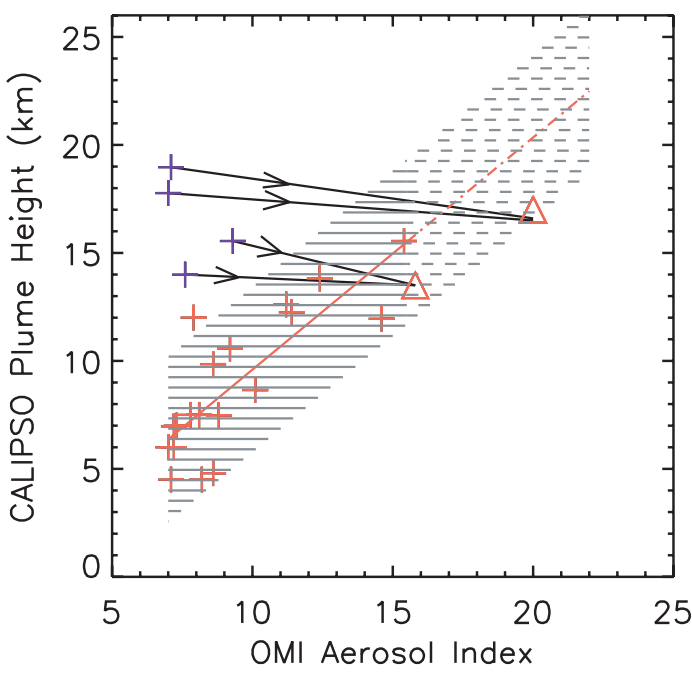

Fig. 4. Scatter-plot of OMI AI and CALIPSO maximum plume height. Red and blue symbols represent "young" and "aged" plumes, respectively, as described in Fig. 3. Solid shaded area shows \pm 2 standard deviation (2-sigma $\approx 3.8 \mathrm{~km}$ ) across the best fit of the young plumes indicated by red crosses. The young-plume data in red triangles were inferred from forward trajectory model calculations and OMI observations 3 or 4 days before the observations (blue crosses). The four aged plumes (4-5 days old) were inside or near the dash shaded area (2-sigma) when they were young (1 day old).

the 2-sigma shaded area and had a lower altitude when they were young (1 day old). This indirectly implies that dilution processes resulting in much smaller optical depths are one of the causes for aged plumes deviating from the AI-height relationship of young plumes. This also indirectly confirms the findings of Real et al. (2007) who showed the important role of dilution/mixing processes on reducing simulated pollutant levels (or concentrations).

\section{Finding the geographical distribution and historical number of high-altitude plumes}

The knowledge of the geographical distribution and historical number of high-altitude biomass burning plumes is critical for further understanding of their associated radiative and climate effects. In this section, we use the threshold value of $\mathrm{AI} \geq 9$ and lower bound Eq. (1) to identify plumes above $5 \mathrm{~km}$ and find the geographic distribution and historical number of high-altitude plumes.

The global distribution of all $\mathrm{AI} \geq 9$ plumes during the entire data record is displayed in Fig. 5 . Given the lower bounding line shown in Fig. 3, these plumes are expected to be at altitudes of $5 \mathrm{~km}$ or higher and represent the total number of observations. That is, these plumes have been counted each day they were observed. This total number is an essential parameter when estimating the influence of pollutants on the UT/LS. Sources of error include the omission of highaltitude plumes due to optical thinness and the limited temporal resolution of polar-orbiting satellites. A careful dustscreening process has helped reduce the possibility of contamination by dust plumes.

North America, Russia/Northeast Asia, and Australia are three major biomass burning source regions yielding large AI values. The number of large AI plumes from each of these three regions during the entire AI record is shown in Fig. 6. The number of the dust plumes screened out for Russia/Northeast Asia is also displayed in the figure. A few removed cases which possibly included smoke mingled with dust do not affect the following conclusion. Typically, large AI plumes occur more frequently over North America (75) than over Russia/Northeas Asia (60) or Australia (28). Previous studies have suggested that Russian fires are largely lower intensity fires, burning mainly surface fuels (Furyaev, 1996; Conard and Ivanova, 1997; Wooster and Zhang, 2004), whereas in North America much higher intensity "crown" fires predominate (Conny and Slater, 2002; Wooster and Zhang, 2004). Crown fires have a larger potential to inject pollutants to higher altitudes, which is consistent with our current analysis. Although originating from a much smaller forest area, the number of Australian high-altitude plumes is also noteworthy. These occurrences mainly resulted from the bushfires in Victoria, Australia during December 2006 and around 7 February 2009. An increase in fire number, duration, and intensity in Australia has been predicted by previous researchers (Beer and Williams, 1995; Williams et al., 2001; Cary, 2002). It will be interesting to see in the coming years if this trend persists.

Although Africa is the single largest continental source of biomass burning emissions (Robert et al., 2009), large AI plumes are absent in the entire climatology. Fires in Africa burn biomass such as savanna and grassland, which produce broader and lower injection layers due to lower fire intensity (Freitas et al., 2007). These lower plume layers result in prevalent small-AI plumes over Africa.

\section{Conclusions}

This study shows the AI data set can be used to identify highaltitude fire plumes. The derived best-fit relationship (Eq. 2) between $\mathrm{AI}$ and maximum plume height for young plumes (within 2 days of the fire) can help validate the vertical placement of smoke plumes in chemical transport models and can also provide a method for the near-real-time monitoring of high-altitude events.

For fire plumes measured with coincident OMI and CALIPSO data from June 2006-February 2009, we found the plume height is $\geq 5 \mathrm{~km}$ when the AI value is $\geq 9$. During the period 1978-2009, large AI ( $\geq 9)$, and therefore likely high-altitude, plumes occurred more frequently over North America $(\sim 75)$ than over Australia $(\sim 28)$ or 


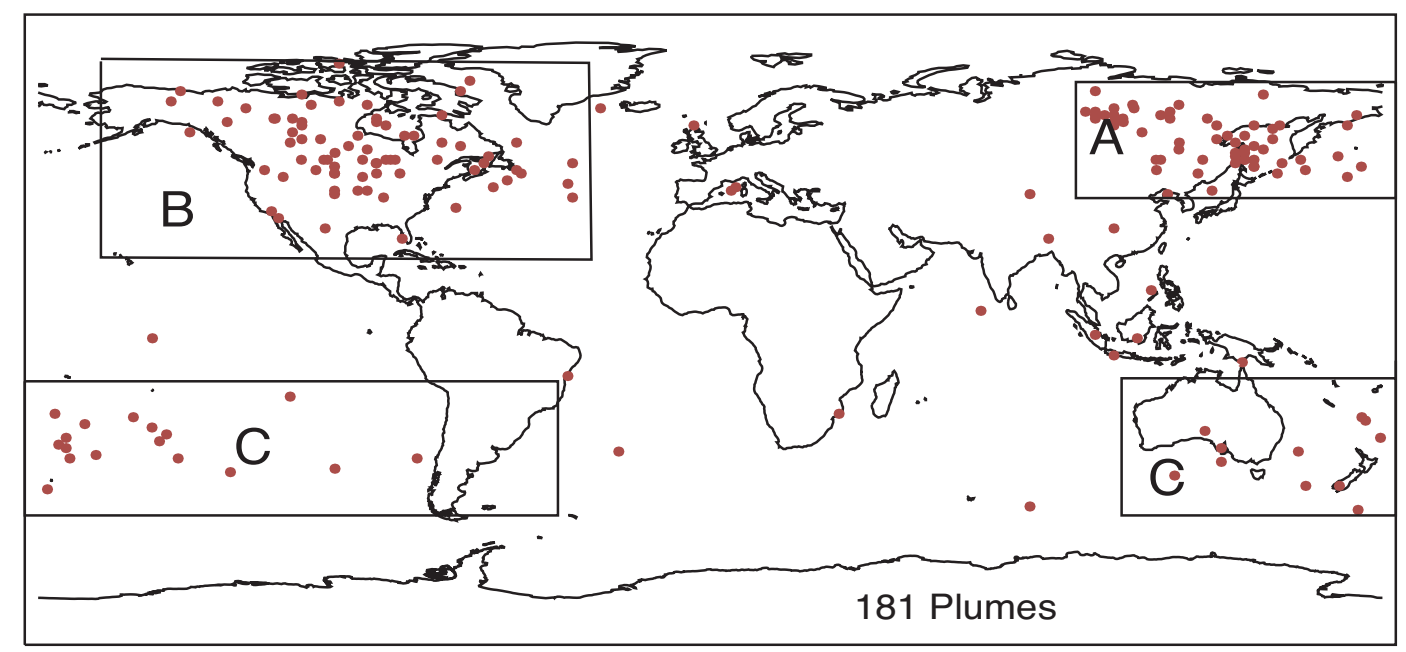

Fig. 5. Global distribution of high-altitude plumes with an AI value $\geq 9$ (i.e. height $\geq 5 \mathrm{~km}$ ) during the entire AI data record ( 31 October 1978 to 13 February 2009). 181 plumes were identified, and 163 of those are located in these three main regions.

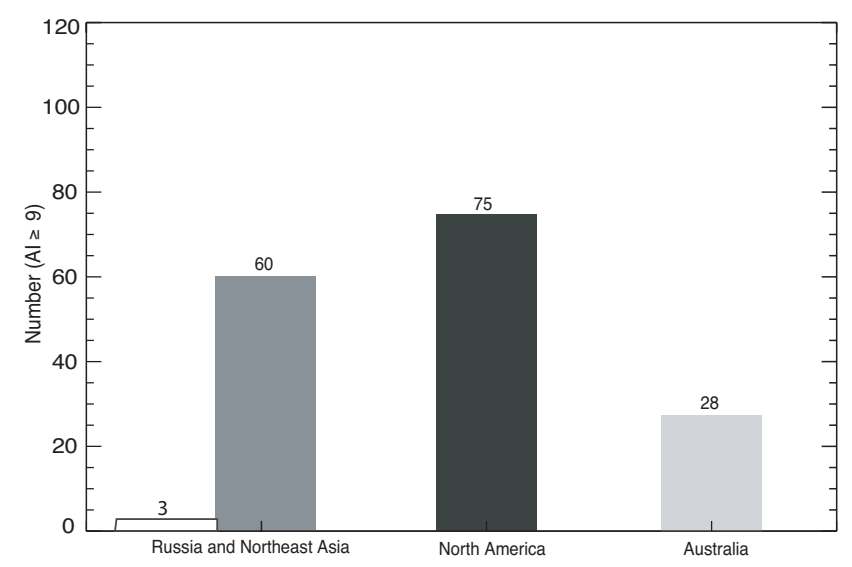

Fig. 6. Number of large-AI ( $\geq 9)$ observations over the three regions (shaded bars) shown in Fig. 5 during the entire AI data record. The white bar represents the number of dust plumes screened out over Russia/Northeast Asia.

Russia/Northeast Asia ( 60). According to the derived relationship, during this time interval, 181 plumes, in various stages of their evolution, reached altitudes above $8 \mathrm{~km}$. Considering their large mass loading and long lifetime, these high-altitude plumes may have the most important impact on the radiative budget, climate, and chemistry. Further tracing their dilution and aging using satellite data may give additional information regarding their transport and fate.

This large AI screening approach provides a useful and fast tool to estimate the approximate top height of plumes. However, this height determination approach is biased in favor of dense high-altitude smoke because of the reduced sensitivity of AI to low-altitude aerosols. Methods for detecting lower plumes and optically-thin high-altitude plumes are be- ing explored. The effectiveness of the linear relationship between AI and maximum plume height for multi-layer plumes or for thick (a few $\mathrm{km}$ ) plumes with a large difference between the maximum and effective heights also needs to be clarified in the future.

Acknowledgements. The authors would like to thank the NASA/GSFC TOMS Ozone Processing Team for AI data. CALIPSO data were obtained from the NASA Langley Research Center Atmospheric Science Data Center. The authors are grateful to the MODIS science team for the production and distribution of the fire data. The authors would also like to acknowledge the helpful advice and commentary of Patrick Hamill. Special appreciation goes to Omar Torres, Ping Yang, and Ali Omar who provided valuable comments and suggestions for understanding AI and CALIPSO aerosol products. Funding for this work was provided by NASA's Atmospheric Composition Program (proposal number: AURA/04-0223 from NRA\# NNH04ZYS004N). A. W. was supported by NASA's Undergraduate Student Research Program.

Edited by: L. M. Russell

\section{References}

Abel, S. J., Haywood, J. M., Highwood, E. J., Li, J., and Buseck, P. R.: Evolution of biomass burning aerosol properties from an agricultural fire in southern Africa, Geophys. Res. Lett., 30(15), 1783, doi:10.1029/2003GL017342, 2003.

Ahmad, S. P., Torres, O., Bhartia, P. K., Leptoukh, G., and Kempler, S. J.: Aerosol Index from TOMS and OMI Measurements, Proc. of the 86th AMS Annual Meeting, February 2006.

Beer, T. and Williams, A.: Estimating Australian forest fire danger under conditions of doubled carbon dioxide concentrations, Climatic Change, 29, 169-188, 1995.

Cary, G. J.: Importance of a changing climate for fire regimes in Australia, in Flammable Australia - The fire regimes and 
biodiversity of a continent, edited by: Bradstock, R. A., Gill, W. J., William, A. M., Cambridge University Press, Cambridge, 27-46, 2002.

Chen, Y., Li, Q., Randerson, J. T., Lyons, E. A., Kahn, R. A., Nelson, D. L., and Diner, D. J.: The sensitivity of CO and aerosol transport to the temporal and vertical distribution of North American boreal fire emissions, Atmos. Chem. Phys., 9, 6559-6580, doi:10.5194/acp-9-6559-2009, 2009.

Cofer, W. R. I., Winstead, E. L., Stocks, B. J., Overbay, L. W., Goldammer, J. G., Cahoon, D. R., and Levine, J. S.: Emissions from boreal forest fires: Are the Atmospheric Impacts Underestimated?, in: Biomass Burning and Global Change, edited by: Levine, J. S., MIT Press, Cambridge, Massachusetts, 1996.

Colarco, P. R., Schoeberl, M. R., Doddridge, B. G., Marufu, L. T., Torres, O., and Welton, E. J.: Transport of smoke from Canadian forest fires to the surface near Washington, D.C.: Injection height, entrainment, and optical properties, J. Geophys. Res., 109, D06203, doi:10.1029/2003JD004248, 2004.

Conard, S. G. and Ivanova, G. A.: Wildfire in Russian boreal forests - potential impacts on fire regime characteristics on emissions and global carbon balance estimates, Environ. Pollut., 98, 305313, 1997.

Conny, J. M. and Slater, J. F.: Black carbon and organic carbon in aerosol particles from crown fires in the Canadian boreal forest, J. Geophys. Res., 107(D11), 4116, doi:10.1029/2001JD001528, 2002.

De Graaf, M. and Stammes, P.: SCIAMACHY Absorbing Aerosol Index - calibration issues and global results from 2002-2004, Atmos. Chem. Phys., 5, 2385-2394, doi:10.5194/acp-5-2385-2005, 2005a.

De Graaf, M., Stammes, P., Torres, O., and Koelemeijer, R. B. A.: Absorbing Aerosol Index: Sensitivity analysis, application to GOME and comparison with TOMS, J. Geophys. Res., 110, D01201, doi:10.1029/2004JD005178, 2005b.

Dirksen, R. J., Boersma, K. F., de Laat, J., Stammes, P., van der Werf, G. R., Val Martin, M., and Kelder, H. M.: An aerosol boomerang: rapid around-the-world transport of smoke from the December 2006 Australian forest fires observed from space, J. Geophys. Res., 114, D21201, doi:10.1029/2009JD012360, 2009.

Duncan, B. N., Strahan, S. E., Yoshida, Y., Steenrod, S. D., and Livesey, N.: Model study of the cross-tropopause transport of biomass burning pollution, Atmos. Chem. Phys., 7, 3713-3736, doi:10.5194/acp-7-3713-2007, 2007.

Eckhardt, S., Prata, A. J., Seibert, P., Stebel, K., and Stohl, A.: Estimation of the vertical profile of sulfur dioxide injection into the atmosphere by a volcanic eruption using satellite column measurements and inverse transport modeling, Atmos. Chem. Phys., 8, 3881-3897, doi:10.5194/acp-8-3881-2008, 2008.

Forster, C., Wandinger, U., Wotawa, G., James, P., Mattis, I., Althausen, D., Simmonds, P., O'Doherty, S., Kleefeld, C., Jennings, S. G., Schneider, J., Trickl, T., Kreipl, S., Jaeger, H., and Stohl, A.: Transport of boreal forest fire emissions from Canada to Europe, J. Geophys. Res., 106(D19), 22887-22906, 2001.

Freitas, S. R., Longo, K. M., Chatfield, R., Latham, D., Silva Dias, M. A. F., Andreae, M. O., Prins, E., Santos, J. C., Gielow, R., and Carvalho Jr., J. A.: Including the sub-grid scale plume rise of vegetation fires in low resolution atmospheric transport models, Atmos. Chem. Phys., 7, 3385-3398, doi:10.5194/acp-7-33852007, 2007.
Fromm, M. D. and Servranckx, R.: Transport of forest fire smoke above the tropopause by supercell convection, Geophys. Res. Lett., 30(10), 1542, doi:10.1029/2002GL016820, 2003.

Fromm, M. D., Shettle, E. P., Fricke, K. H., et al.: Stratospheric impact of the Chisholm pyrocumulonimbus eruption: 2. Vertical profile perspective, J. Geophys. Res., 113, D08203, doi:10.1029/2007JD009147, 2008b.

Fromm, M. D., Torres, O., Diner, D., et al.: Stratospheric impact of the Chisholm pyrocumulonimbus eruption: 1. Earthviewing satellite perspective, J. Geophys. Res., 113, D08202, doi:10.1029/2007JD009153, 2008a.

Furyaev, V. V.: Pyrological regimes and dynamics of the southern taiga forests in Siberia, in: Fire in Ecosystems of Boreal Eurasia, edited by: Goldammer, J. G. and Furyaev, V. V., Kluwer Acad., Norwell, Mass., 168-185, 1996.

Gautam, R., Hsu, N. C., Lau, K.-M., and Kafatos, M.: Aerosol and rainfall variability over the Indian monsoon region: distributions, trends and coupling, Ann. Geophys., 27, 3691-3703, 2009, http://www.ann-geophys.net/27/3691/2009/.

Ginoux, P., Chin, M., Tegen, I., Prospero, J. M., Holben, B., Dubovik, O., and Lin, S.-J.: Sources and distributions of dust aerosols simulated with the GOCART model, J. Geophys. Res., 106(D17), doi:10.1029/2000JD000053, 2001.

Guan, H., Chatfield, R. B., Freitas, S. R., Bergstrom, R. W., and Longo, K. M.: Modeling the effect of plume-rise on the transport of carbon monoxide over Africa with NCAR CAM, Atmos. Chem. Phys., 8, 6801-6812, doi:10.5194/acp-8-6801-2008, 2008.

Herman, J. R., Bhartia, P. K., Torres, O., Hsu, C., Seftor, C., and Celarier, E.: Global distribution of UV-absorbing aerosols from Nimbus 7/TOMS data, J. Geophys.Res., 102(D14), 16911$16922,1997$.

Hsu, N. C., Si-Chee, T., King, M. D., and Herman, J. R.: Aerosol properties over bright-reflecting source regions, IEEE Trans. Geosci. Rem. Sens., 42, 557-569, 2004.

IPCC: Climate Change 2007: The Physical Science Basis, Contribution of Working Group I to the Fourth Assessment Report of the Intergovernmental Panel on Climate Change, edited by: Solomon, S., Qin, D., Manning, M., Chen, Z., Marquis, M., Averyt, K. B., Tignor, M., and Miller, H. L., Cambridge University Press, Cambridge, United Kingdom and New York, NY, USA, 996 pp., 2007.

Jeong, M.-J. and Hsu, N. C.: Retrievals of aerosol single-scattering albedo and effective aerosol layer height for biomass-burning smoke: Synergy derived from “A-Train” sensors, Geophys. Res. Lett., 35, L24801, doi:10.1029/2008GL036279, 2008.

Jost, H.-J., Drdla, K., Stohl, A., Pfister, L., Loewenstein, M., Lopez, J. P., Hudson, P. K., Murphy, D. M., Cziczo, D. J., Fromm, M. D., Bui, T. P., Dean-Day, J., Gerbig, C., Mahoney, M. J., Richard, E. C., Spichtinger, N., Pittman Vellovic, J., Weinstock, E. M., Wilson, J. C., and Xueref, I.: In-Situ observations of mid-latitude forest fire plumes deep in the stratosphere, Geophys. Res. Lett., 31, L11101, doi:10.1029/2003GL019253, 2004.

Kahn, R. A., Chen, Y., Nelson, D. L., Leung, F.-Y., Li, Q., Diner, D. J., and Logan, J. A.: Wildfire smoke injection heights: Two perspectives from space, Geophys. Res. Lett., 35, L04809, doi:10.1029/2007GL032165, 2008.

Kiss, P., Janosi, I. M., and Torres, O.: Early calibration problems detected in TOMS Earth-Probe aerosol signal, Geophys. Res. Lett., 
34, L07803, doi:10.1029/2006GL028108, 2007.

Kuester, M. A., Marshall, J., and Emery, W. J.: Remote sensing and modeling of wildfires, Geoscience and Remote Sensing Symposium 2005, IGARSS '05 Proceedings, 2005 IEEE International, 5729-5732, 2005.

Li, J., Carlson, B. E., and Lacis, A. A.: A study on the temporal and spatial variability of absorbing aerosols using Total Ozone Mapping Spectrometer and Ozone Monitoring Instrument Aerosol Index data, J. Geophys. Res., 114, D09213, doi:10.1029/2008JD011278, 2009.

Li, Q., Jiang, J. H., Wu, D. L., Read, W. G., Livesey, N. J., Waters, J. W., Zhang, Y., Wang, B., Filipiak, M. J., Davis, C. P., Turquety, S., Wu, S., Park, R. J., Yantosca, R. M., and Jacob, D. J.: Convective outflow of South Asian pollution: A global CTM simulation compared with EOS MLS observations, Geophys. Res. Lett., 32, L14826, doi:10.1029/2005GL022762, 2005.

Luderer, G., Trentmann, J., Winterrath, T., Textor, C., Herzog, M., Graf, H. F., and Andreae, M. O.: Modeling of biomass smoke injection into the lower stratosphere by a large forest fire (Part II): sensitivity studies, Atmos. Chem. Phys., 6, 5261-5277, doi:10.5194/acp-6-5261-2006, 2006.

Mazzoni, D., Logan, J. A., Diner, D., Kahn, R., Tong, L., and Li, Q.: A data-mining approach to associating MISR smoke plume heights with MODIS fire measurements, Remote Sens. Environ., 107, 149-158, doi:10.1016/j.rse.2006.08.014, 2007.

Penning de Vries, M.: Interactive comment on "A multi-decadal history of biomass burning plume heights identified using aerosol index measurements" by H. Guan et al., Atmos. Chem. Phys. Discuss., 10, C362-C363, 2010.

Randerson, J. T., Liu, H., Flanner, M. G., Chambers, S. D., Jin, Y., Hess, P. G., Pfister, G., Mack, M. C., Treseder, K. K., Welp, L. R., Chapin, F. S., Harden, J. W., Goulden, M. L., Lyons, E., Neff, J. C., Schuur, E. A. G., and Zender C. S.: The Impact of Boreal Forest Fire on Climate Warming, Science, 314, 1130 1132, 10.1126/science.1132075, 2006.

Real, E., Law, K. S., Weinzierl, B., et al.: Processes influencing ozone levels in Alaskan forest fire plumes during longrange transport over the North Atlantic, J. Geophys. Res., 112, D10S41, doi:10.1029/2006JD007576, 2007.

Reid, J. S., Hobbs, P. V., Ferek, R. J., Blake, D. R., Martins, J. V., Dunlap, M. R., and Liousse, C.: Physical, chemical, and optical properties of regional hazes dominated by smoke in Brazil, J. Geophys. Res., 103, 32059-32080, 1998.

Roberts, G., Wooster, M. J., and Lagoudakis, E.: Annual and diurnal african biomass burning temporal dynamics, Biogeosciences, 6, 849-866, doi:10.5194/bg-6-849-2009, 2009.

Rosenfeld, D., Fromm, M., Trentmann, J., Luderer, G., Andreae, M. O., and Servranckx, R.: The Chisholm firestorm: observed microstructure, precipitation and lightning activity of a pyro-cumulonimbus, Atmos. Chem. Phys., 7, 645-659, doi:10.5194/acp-7-645-2007, 2007.

Schoeberl, M. and Newman, P. A.: A multiple-level trajectory analysis of vortex filaments, J. Geophys. Res., 100(D12), 2580125815, 1995.

Swap, R. J., Annegarn, H. J., Suttles, J. T., King, M. D., Platnick, S., Privette, J. L., and Scholes, R. J.: Africa burning: A thematic analysis of the Southern African Regional Science Initiative (SAFARI 2000), J. Geophys. Res., 108(D13), 8465, doi:10.1029/2003JD003747, 2003.
Thomason, L. W., Pitts, M. C., and Winker, D. M.: CALIPSO observations of stratospheric aerosols: a preliminary assessment, Atmos. Chem. Phys., 7, 5283-5290, doi:10.5194/acp-7-52832007, 2007.

Torres, O., Bhartia, P. K., Herman, J. R., Ahmad, Z., and Gleason, $\mathrm{J}$.: Derivation of aerosol properties from satellite measurements of backscattered ultraviolet radiation: Theoretical basis, J. Geophys. Res., 103, 17099-17110, doi:10.1029/98JD00900, 1998.

Torres, O., Tanskanen, A., Veihelmann, B., Ahn, C., Braak, R., Bhartia, P. K., Veefkind, P., and Levelt, P.: Aerosols and surface UV products from Ozone Monitoring Instrument observations: An overview, J. Geophys. Res., 112, D24S47, doi:10.1029/2007JD008809, 2007.

Trentmann, J., Luderer, G., Winterrath, T., Fromm, M. D., Servranckx, R., Textor, C., Herzog, M., Graf, H.-F., and Andreae, M. O.: Modeling of biomass smoke injection into the lower stratosphere by a large forest fire (Part I): reference simulation, Atmos. Chem. Phys., 6, 5247-5260, doi:10.5194/acp-65247-2006, 2006.

Val Martin, M., Logan, J. A., Kahn, R. A., Leung, F.-Y., Nelson, D. L., and Diner, D. J.: Smoke injection heights from fires in North America: analysis of 5 years of satellite observations, Atmos. Chem. Phys., 10, 1491-1510, doi:10.5194/acp-10-14912010, 2010.

Vaughan, M., Young, S., Winker, D., Powell, K., Omar, A., Liu, Z., Hu, Y., and Hosteler, C.: Fully automated analysis of spacebased lidar data: an overview of CALIPSO retrieval algorithms and data products, Proc. SPIE, 5575, 16-30, 2004.

Waibel, A. E., Fischer, H., Wienhold, F. G., Siegmund, P. C., Lee, B., Strom, J., Lelieveld, J., and Crutzen, P. J.: Highly elevated carbon monoxide concentrations in the upper troposphere and lowermost stratosphere at northern midlatitudes during the STREAM II summer campaign in 1994, Chemosphere - Global Change Science, 1, 233-248, 1999.

Westphal, D. L. and Toon, O. B.: Simulations of microphysical, radiative, and dynamical processes in a continental-scale forest fire smoke plume, J. Geophys. Res., 96(D12), 22379-22400, doi:10.1029/91JD01956, 1991.

Williams, A. A. J., Karoly, D. J., and Tapper, N.: The sensitivity of Australian fire danger to climate change, Climatic Change, 49, 171-191, 2001.

Winker, D. M., Hunt, W. H., and McGill, M. J.: Initial performance assessment of CALIOP, Geophys. Res. Lett., 34, L19803, doi:10.1029/2007GL030135, 2007.

Wong, J. and Li, Z.: Retrieval of optical depth for heavy smoke aerosol plumes: Uncertainties and sensitivities to the optical properties, J. Atmos. Sci., 59, 250-261, 2002.

Wooster, M. J. and Zhang, Y. H.: Boreal forest fires burn less intensely in Russia than in North America, Geophys. Res. Lett., 31, L20505, doi:10.1029/2004GL020805, 2004. 